\title{
ШЛЯХИ ЗНИЖЕННЯ РОЗПОВСЮДЖЕННЯ МУЛЬТИРЕЗИСТЕНТНОГО ТУБЕРКУЛЬОЗУ 3 ПОГЛЯДУ ФТИЗІОЕПІДЕМІОЛОГІї
}

ДВНЗ «Тернопільський державний медичний університет імені І.Я. Горбачевського МОЗ України»

\begin{abstract}
Мета: обґрунтувати шляхи зниження захворюваності на туберкульоз, зокрема мультирезистентний, на підставі знання закономірностей фтизіоепідеміології цієї недуги.

Матеріали і методи. В основу роботу покладено літературні дані, особисті багаторічні спостереження та дослідження.

Результати. Захворюваність на вперше діагностований деструктивний туберкульоз в області з 2010 по 2013 рік знизилась $з$ 47,9\% до 40,2\%. Рецидиви 3 деструкціями зросли з 51,9\% до 79,2\%, а видужання настало лише у 41,3\% хворих. Решта пацієнтів є практично мультирезистентними хронічними хворими, що становить епідемічну загрозу.

Висновки. Для зниження розповсюдження туберкульозу необхідно удосконалювати шляхи його виявлення, лікування до припинення бактеріовиділення, загоєння порожнин розпаду і стабілізації туберкульозного процесу.
\end{abstract}

КЛЮЧОВІ СЛОВА: туберкульоз, мультирезистентність, фтизіоепідеміологія.

Туберкульоз, як захворювання, відомий з давніх давен. Ця інфекційна хвороба, яку спричиняють мікобактерії туберкульозу, перебігає з періодичними загостреннями, рецидивами та ремісіями, уражає переважно найбідніші, соціально дезадаптовані, групи населення. За даними ВООЗ, останніми роками боротьба з туберкульозом у Європейському регіоні має позитивні зміни. Україна також досягла певних успіхів у подоланні туберкульозу, проте на цьому фоні зросла кількість хворих на хіміорезистентні форми туберкульозу. Факторами, що обумовлюють високий рівень захворюваності та поширення його мультирезистених форм, є недостатнє і несвоєчасне виявлення хворих на заразні форми туберкульозу. Захворюваність на бактеріальні форми туберкульозу становить 30,8 на 100 тис. населення; ефективність лікування вперше виявлених хворих сягає лише 55,0\%, з рецидивом - 34,2\% [6] . Показник смертності у 2012 році становив 15,1 на 100 тис. населення. Загальний відсоток хворих, що померли від туберкульозу, протягом одного року спостереження по Україні склав, в середньому, 17,7, у Тернопільській області - 30,4. Це свідчить про незадовільну роботу з раннього виявлення туберкульозу, як і недостатню санпросвітню роботу серед населення області.

Надзвичайно актуальною сьогодні є потреба національної політики щодо формування у населення відповідального ставлення до власного здоров'я, як найвищої особистої та суспільної цінності, починаючи з дитинства, формування

(C) I.T. П’ятночка, C.I. Корнага, Н.В. Тхорик, 2014 навичок здорового способу життя як базової складової виховання духовної та фізично здорової особистості [2]. Усі ці компоненти (чітке уявлення про збудника, клінічні прояви хвороби, діагностику, лікування та профілактику) в комплексі, з огляду на їх практичне застосування, поєднуються в єдине поняття - подолання туберкульозу на основі знань практичної фтизіоепідеміології.

Мета дослідження полягає в обґрунтуванні шляхів зниження захворюваності на туберкульоз, зокрема мультирезистентний, на підставі знання закономірностей фтизіоепідеміології цієї недуги.

Матеріали і методи. В основу роботи покладено літературні дані, особисті багаторічні спостереження та дослідження.

Результати дослідження та їх обговорення. Епідемічний процес при туберкульозі виникає і підтримується при взаємодії трьох обов'язкових його частин: а) джерела збудника туберкульозу; б) механізм передачі; в) сприйнятливість населення до туберкульозної інфекції. При розриві цієї взаємодії і вилученні хоча б одного елемента епідеміологічний процес припиняється. Епідемічний процес при туберкульозі - це процес взаємодії людини і популяції збудника туберкульозу. Цей процес, з одного боку, є явищем біологічним, з іншого - соціальним. $€$ певні біологічні закони розвитку цього процесу, що полягають у постійному пристосуванні мікобактерій туберкульозу до мінливих умов зовнішнього середовища.

Основним джерелом туберкульозної інфекції є хворий на туберкульоз легень, який виділяє 
мікобактерії з мокротинням при кашлі, розмові, чханні. Особливість пацієнта, як джерела інфекції, полягає в тому, що він може виділяти мікобактерії туберкульозу постійно чи періодично протягом багатьох років. Хворий на деструктивний туберкульоз легень може виділяти з мокротинням від 15 млн до 7 млрд мікобактерій протягом доби. Джерелом інфекції можуть бути також свійські тварини, передовсім велика рогата худоба, від якої людина заражається бичачим типом мікобактерій, в основному через молоко.

Туберкульоз поширюється переважно повітряно-краплинним шляхом. Однак краплинне інфікування відбувається не так часто і лише за певних умов. Значно більше значення має пилова інфекція. Висохлі крапельки мокротиння на підлозі, різних предметах піднімаються в повітря у вигляді інфікованого пилу. Чим менші ці частинки, тим більш імовірно, що вони через дихальні шляхи досягають альвеол, позбавлених місцевого захисту. Рідше інфекція потрапляє через ушкоджені бронхи або мигдалики і лімфатичні вузли ротової частини глотки (кільце Пирогова). Зараження через інфікований пил відбувається переважно в житлі туберкульозного хворого. Зараження мікобактеріями туберкульозу може відбуватися також аліментарним, контактним шляхом і, надзвичайно рідко, внутрішньоутробно.

Заразливість для оточуючих людей неоднакова. Вона залежить від багатьох факторів і умов. Важливе значення має масивність бактеріовиділення і його тривалість.

Мікобактерії туберкульозу мають значну стійкість до різних фізичних і хімічних агентів. Висохлі мікобактерії зберігають патогенність для морських свинок протягом $1-1 \frac{1}{2}$ року. У вуличному пилу мікобактерії зберігаються протягом 10 днів. Ультрафіолетові промені вбивають мікобактерії через 2-3 хвилини. У вологому мокротинні мікобактерії гинуть при кип'ятінні протягом 5 хвилин, у висохлому мокротинні - лише через 45 хвилин. Надійної дезінфекції мокротиння можна досягти при використанні препаратів, що виділяють активний хлор (3-5\% розчин хлораміну протягом 5 годин, 1-2\% розчин хлораміну активованого сульфатом амонію протягом 3 годин, 10-20\% розчин хлорного вапна протягом $2 \frac{1}{2}$ годин, а також бактерицидного ультрафіолетового опромінення [5].

Людина може захворіти на туберкульоз лише при попаданні в ії організм мікобактерій туберкульозу. Однак людині притаманна відносна індивідуальна резистентність до туберкульозу, про що свідчить ряд факторів. Залежно від епідеміологічної ситуації мікобактеріями туберкульозу інфікується більшість людей, але захворюють лише незначна частина інфікованих - 5-15\% i, переважно, в перші 1-2 роки після зараження. Найчастіше туберкульоз виявляють у членів родини хворого, що перебувають з ним у тісному контакті. У селі з великою кількістю населення при частому спілкуванні хворого з односельцями може заразитися 50-100 чоловік [8].

Загалом більшість людей (85-90\%) успішно справляються з первинним зараженням мікобактеріями туберкульозу. Однак слід пам'ятати, що опірність людини до туберкульозу протягом життя неоднакова. Найнебезпечнішим є зараження в ранньому дитячому віці. При недавньому інфікуванні ризик розвитку захворювання в 10 разів більший, ніж якщо інфікування відбулося давно. У дорослих, що були раніше інфіковані, забезпечується захист від реінфекції приблизно на $40 \%$ [8].

Останніми роками ризик інфікування збільшився в десятки разів і продовжує щорічно зростати. Оскільки сучасні заходи щодо розриву ланцюга передачі туберкульозної інфекції від хворого до здорового недостатньо ефективні, несвоєчасне виявлення хворих, погана їх ізоляція та малоефективне лікування збільшують поширення туберкульозної інфекції. Цьому сприяють низька санітарна грамотність населення, недостатня робота у вогнищах туберкульозної інфекції. Проте, навіть в умовах постійного сімейного контакту з бактеріовиділювачами, не всі особи стають інфікованими. Оскільки схильність до туберкульозу визначається не лише факторами зовнішнього середовища, мікобактеріями туберкульозу, але і внутрішніми властивостями організму, зокрема спадковими (генетичними) факторами.

Якщо підходити до туберкульозу з позицій генетики, то його можна віднести до групи захворювань зі спадковою схильністю чи багатофакторних захворювань. У сім'ях пробандів (пробанд - це хворий, з якого починається складання родоводу), котрі хворіли на деструктивний бацилярний туберкульоз, частота туберкульозу серед рідних першої лінії родоводу (діти, сестри і брати, батьки пробандів) значно перевищувала частоту захворювання серед всього населення не лише за наявності сімейного контакту (у 7,2 разу), але і за відсутності тісного сімейного контакту з пробандами (у 5 разів) і навіть 3 недеструктивним туберкульозом легень.

Стосовно асоціації між захворюванням на туберкульоз і різними генетичними маркерами, такими як антигени групи крові, з'ясувалося, що вірогідність захворювання на туберкульоз у осіб 3 групою крові В (III) вірогідно вища, ніж з групою крові A (II) і AB (IV). Достовірно більше спостерігається хворих на туберкульоз з групою крові AB (IV), а у осіб з групою крові A (II) - більш важкий перебіг. Серед вперше виявлених хво- 
рих на деструктивний туберкульоз легень частіше спостерігаються особи О (I) і рідше з групою A (II) [6]. Кращі результати лікування спостерігалися у хворих з В (III), найнижчі у пацієнтів з А (II) групою крові. Загоєння каверн значно частіше відбувалося в осіб з Rh (-) приналежністю [3].

Лікування хворих на туберкульоз - найважливіша невід'ємна ланка в розриві епідеміологічного ланцюга, що дає змогу досягти загоєння туберкульозного процесу та відновлення працездатності і соціального статусу. Основними ознаками, що підтверджують ефективність лікування, $€$ стійке припинення бактеріовиділення, підтверджене бактеріоскопічним та культуральним методами, загоєння порожнин розпаду, стабілізація процесу, а також досягнення медико-соціальної та трудової реабілітації.

Останніми роками, на тлі поступової стабілізації епідеміологічного процесу, велику загрозу становить значне поширення мультирезистентного туберкульозу. Це найнебезпечніша форма туберкульозу, при якій мікобактерії є стійкими до двох найефективніших протитуберкульозних препаратів (ізоніазиду та рифампіцину), а самі мікобактерії мають більшу вірулентність і набагато легше передаються від хворої до здорової людини. Хворі на мультирезистентний туберкульоз потребують обов'язкової госпіталізації та тривалого інтенсивного лікування. Сьогодні лікування хворих на туберкульоз проводиться згідно з уніфікованим клінічним протоколом медичної допомоги (УКПМД) «Туберкульоз» (2012). Стаціонарне лікування проводиться до припинення бактеріовиділення, що підтверджується методом мікроскопії мазка мокротиння [7]. Ця унітарна програма є доволі жорсткою, яка не допускає відхилень від запрограмованого методу лікування та організаційних форм.

Подальше лікування проводиться в домашніх умовах під «медичним» наглядом. Таке лікування не є достатньо ефективним, оскільки загоєння порожнин розпаду констатовано лише у 63,1\% хворих на вперше діагностований деструктивний туберкульоз легень (Тернопільська область, 2011-2012 роки). До речі, захворюваність на вперше діагностований деструктивний туберкульоз в області з 2010 по 2013 рік знизилась 3 47,9\% до 40,2\%. Водночас рецидиви з деструкціями зросли з 51,9\% до 79,2\%, а видужання відбулося лише у 41,3\% хворих. Решта неефективно пролікованих пацієнтів є практично мультирезистентними «хроніками» і становлять дуже небезпечну епідеміологічну загрозу [4]. 3 цього випливає, що, на відміну від унітарної, слід дотримуватись більш гнучкої програми лікування, яка передбачає для різних контингентів хворих різні методи та організаційні форми лікування. Ефективність лікування повинна підтверджувати- ся стійким припиненням бактеріовиділення, загоєнням порожнин розпаду і стабілізацією процесу. До того ж в окремих випадках виправданим $€$ проведення протирецидивних курсів хіміотерапії, що значною мірою запобігало б виникненню рецидивів. Загалом для досягнення кращих результатів лікування потрібно, в окремих випадках, проводити більш тривалу стаціонарну комплексну терапію. Значно ширше слід застосовувати хірургічні втручання, зокрема при мультирезистентному туберкульозі легень, а також колапсотерапевтичні. Застосуванням пневмоперитонеуму на фоні інтенсивної хіміотерапії ми досягали видужання у окремих хворих на мультирезистентний деструктивний туберкульоз легень [1].

Паліативне лікування необхідно проводити в спеціалізованих стаціонарах або в окремо виділених палатах тубстаціонарів. Виписка пацієнтів з незагоєними порожнинами розпаду на амбулаторне лікування, зокрема паліативне, створює велику загрозу розповсюдження туберкульозної інфекції, передусім мультирезистентого туберкульозу, серед членів сім'ї, близького оточення і населення взагалі. Заходи із знешкодження туберкульозної інфекції в домашніх умовах, в переважній більшості тубвогнищ, є недостатньо ефективними через відсутність надійних засобів дезінфекції, як хімічних так і фізичних. Ці можливості в протитуберкульозних стаціонарах є в повному об'ємі.

Інший шлях зниження поширеності мультирезистентного туберкульозу полягає в попередньому «сортуванні» вперше виявлених хворих, яких спочатку необхідно розміщувати в окремі палати на час визначення чутливості мікобактерій туберкульозу до хіміопрепаратів. Оскільки нерідко хворі на вперше діагностований мультирезистентний туберкульоз тривалий час перебувають у загальних палатах з пацієнтами, які не виділяють або виділяють чутливі до протитуберкульозних препаратів мікобактерії. У таких випадках і відбувається внутрішньолікарняне розповсюдження мультирезистентного туберкульозу. Підтвердженням цього є те, що у відділенні хворих на вперше діагностований туберкульоз легень мультирезистентний констатовано у 20102014 роках у 7, 12, 19, 23 і 33 пацієнтів відповідно. Отже, при госпіталізації хворих і на вперше діагностований туберкульоз легень потрібно дотримуватися превентивних заходів щодо внутрішньолікарняного розповсюдження мультирезистентності.

Надзвичайно велике значення в розриві епідеміологічного процесу мають профілактичні заходи. Це, передусім, щеплення та ревакцинація, хіміопрофілактика, оздоровчо-профілактична робота в тубвогнищах, як і серед контингентів груп ризику.

Важливою складовою протитуберкульозної роботи є санпросвітня робота серед хворих на 
туберкульоз, контактів і населення в цілому. Санітарно-просвітня робота - це безперервний процес, який полягає у висвітленні властивостей збудника туберкульозу, шляхів його передачі, проявів захворювання, методів лікування і профілактики. На жаль, санітарно-просвітня робота не проводиться на належному рівні, зокрема індивідуальна робота з пацієнтами. Підтвердженням цього є слабка загальна орієнтація з питань туберкульозу у 15,7\% пацієнтів, які знаходилися на стаціонарному лікуванні і вже закінчили інтенсивну фазу [7]. У цьому є велика вина медичного персоналу, передусім фтизіатрів.

\section{Висновки}

Для зниження розповсюдження туберкульозу, зокрема мультирезистентного, необхідне удосконалення шляхів його виявлення, тривале комплексне лікування до стійкого припинення бактеріовиділення, загоєння порожнин розпаду і стабілізації туберкульозного процесу, з використанням доступних апробованих адекватних методів (хірургічні, колапсотерапевтичні, в окремих випадках і протирецидивні курси хіміотерапіі).

3 метою обмеження внутрішньолікарняного поширення мультирезистентності серед вперше діагностованих хворих слід проводити їх попередню короткочасну «ізоляцію» в окремих палатах до визначення медикаментозної чутливості мікобактерій.

Необхідно покращити санпросвітню роботу серед хворих на туберкульоз і населення взагалі, прищеплюючи навички здорового способу життя, правильного розуміння і виконання оздоровчо-профілактичних заходів.

Перспективи подальших досліджень спрямовані на поглиблене вивчення шляхів зниження мультирезистентного туберкульозу серед сільських мешканців.

\section{Список літератури}

1. Пневмоперитонеум у комплексному лікуванні хворих на хіміорезистентний туберкульоз легень / І. Т. П'ятночка, С. І. Корнага, Ю. В. Довбуш [та ін.] // Шпитальна хірургія. - 2011. - № 3. - С. 86-88.

2. Пульмонологія та фтизіатрія: національний підручник у 2-х т. / за ред. Ю. І. Фещенка, В. П. Мельника, І. Г. Ільницького. - К.-Л. : Атлас, 2011.- 1362 с.

3. П'ятночка І. Т. Ефективність лікування хворих на туберкульоз легень при різній групові та резус-приналежності крові / І. Т. П'ятночка, С. І. Корнага, Н. В. Корнага // Інфекційні хвороби. - 2007. - № 1. - С. 41-43.

4. П'ятночка І. Т. Про рецидиви туберкульозу легень / І. Т. П'ятночка, С. І. Корнага, Н. В. Тхорик // Вісн. наук. досліджень. - 2014. - № 2. - С. 53-54.

5. Туберкульоз в Україні (аналітично-статистичний довідник за 2011-2012 роки). - К., 2013. - 122 с.

6. Туберкулёз органов дыхания : рук-во для врачей / А. Г. Хоменко, М. М. Авербах, А. А. Александрова [и др.]; под ред. А. Г. Хоменко. - 2-е изд., перераб. и доп. - М. : Медицина, 1988. - 576 с.

7. Уніфікований клінічний протокол первинної, вторинної (спеціалізованої) та третинної (високоспеціалізованої) медичної допомоги. Туберкульоз. - К., 2012. - 171 с.

8. Фещенко Ю. І. Фтизіоепідеміологія / Ю. І. Фещенко, В. М. Мельник. - К. : Здоров'я, 2004. - 624 с.

\section{ПУТИ СНИЖЕНИЯ РАСПРОСТРАНЕНИЯ МУЛЬТИРЕЗИСТЕНТНОГО ТУБЕРКУЛЕЗА С ТОЧКИ ЗРЕНИЯ ФТИЗИОЭПИДЕМИОЛОГИИ}

И.Т. Пятночка, С.И. Корнага, Н.В. Тхорик

ГВУЗ «Тернопольский государственный медицинский университет имени И.Я. Горбачевского МЗ Украины»

Цель: обосновать пути снижения заболеваемости туберкулёзом, в частности мультирезистентным, на основании знаний закономерностей фтизиоэпидемиологии зтой болезни.

Материалы и методы. В основу работы положены литературные данные, личные многолетние наблюдения и исследования.

Результаты. Заболеваемость впервые диагностированным деструктивным туберкулёзом в области с 2010 по 2013 годы снизилась с 47,9\% до 40,2\%. Рецидивы с деструкциями возросли с 51,9\% до 79,2\%, а выздоровление наступило лишь у 41,3\% больных. Остальные пациенты являются практически мультирезистентными хроническими больными, что составляет эпидемическую угрозу.

Выводы. Для снижения распространения туберкулёза необходимо совершенствовать пути его выявления, лечение до прекращения бактериовыделения, заживления полостей распада и стабилизации туберкулёзного процесса.

КЛЮЧЕВЫЕ СЛОВА: туберкулёз, мультирезистентность, фтизиоэпидемиология. 
WAYS OF DECLINE OF MULTIREZISTENS TUBERCULOSIS DISTRIBUTION FROM THE POINT OF PHTHISIOEPIDEMIOLOGY

I.T. Pyatnochka, S.I. Kornaha, N.V. Thoryk

SHEE «Ternopil State Medical University named by I.Ya. Horbachevskyi Ministry of Health of Ukraine»

Purpose: to ground the ways of morbidity tuberculosis decline in particular, multirezistens, on the basis of conformities knowledge to law of this illness phthisioepidemiology.

Materials and methods. Literary data, personal long-term supervisions and researches are fixed in basis.

Results. Morbidity on the first diagnosed destructive tuberculosis in region from 2010 to 2013 decreased from $47,9 \%$ to $40,2 \%$. Relapses with destructions grew from $51,9 \%$ to $79,2 \%$, and recovery came only at $41,3 \%$ patients. Other patients are practically multirezistens "chronics" and very dangerous epidemiology threat.

Conclusions. For the decline of distribution of tuberculosis it is necessary to perfect the ways of its exposure, treatment to stopping of bacterioexcretion, cavities cicatrization of disintegration and stabilizing of tubercular process.

KEY WORDS: tuberculosis, multiresistens, phthisioepidemiology.

Рукопис надійшов до редакції 05.11.2014 р.

Відомості про авторів:

П'ятночка Іван Теодорович, - д.мед.н., проф., ДВНЗ «Тернопільський державний медичний університет імені І.Я. Горбачевського МОЗ України», тел.: +38(0352) 52-59-29.

Корнага Світлана Іванівна - д.мед.н., проф. кафедри пропедевтики внутрішньої медицини та фтизіатрії ДВНЗ «Тернопільський державний медичний університет імені І.Я. Горбачевського МОЗ України», тел.: +38(0352) 52-59-29.

Тхорик Наталія Василівна - лікар-фтизіатр Шумської ЦРЛ, тел.: +38(03558) 2-14-73. 